\title{
Genetic analyses determine connectivity among cave and surface populations of the Jamaican endemic freshwater crab Sesarma fossarum in the Cockpit Country
}

\author{
Manuel Stemmer ${ }^{1,2^{*}}$ and Christoph D. Schubart ${ }^{1}$ \\ ${ }^{1}$ Zoology/Evolutionary Biology, Regensburg University, 93040 Regensburg, Germany \\ ${ }^{2}$ Centre for Organismal Studies (COS), Heidelberg University, Im Neuenheimer Feld 230, Heidelberg, Germany
}

\begin{abstract}
The Jamaican freshwater crab Sesarma fossarum (Decapoda: Brachyura: Sesarmidae) is endemic to western central Jamaica where it occurs in cave and surface streams of karst regions. In the present study, we examine the population genetic structure of the species, providing evidence for intraspecific differentiation and genetic substructure among twelve sampled populations. Interestingly, crabs from caves appear genetically undistinguishable from representatives of nearby surface waters, despite previously observed and described morphometric differentiation. In contrast, genetic isolation takes place among populations from rivers and caves belonging to different watersheds. In one case, even populations from different tributaries of the same river were characterized by different genotypes. Overall, the species shows low haplotype and nucleotide diversities, which indicates a high homogeneity and point towards a relatively recent intraspecific radiation and diversification. Our results on the genetic diversification of $S$. fossarum helps to reconstruct unknown subterranean water flow and cave connections in its native range, allowing prediction of its further dispersal and differentiation potential. Unfortunately, its natural habitat of Jamaican cockpit karst, which also is home to several other endemic species and is a globally-recognized Key Biodiversity Area, is under imminent threat of intensive bauxite mining.
\end{abstract}

Keywords: endemism; biodiversity; troglophile; conservation; karst

Received 09 March 2015; Revised 11 October 2015; Accepted 4 November 2015

Citation: Stemmer M. and Schubart C.D., 2016. Genetic analyses determine connectivity among cave and surface populations of the Jamaican endemic freshwater crab Sesarma fossarum in the Cockpit Country. International Journal of Speleology, 45 (1), 35-41. Tampa, FL (USA) ISSN 0392-6672 http://dx.doi.org/10.5038/1827-806X.45.1.1912

\section{INTRODUCTION}

The Cockpit Country in western central Jamaica is a typical example of polygonal karst (Sweeting, 1958; Fincham, 1997; Chenoweth et al., 2001). This special environment provides enormous habitat richness and is the key for the very high biodiversity that can be found associated to it (Hamilton-Smith, 2001; Clements et al., 2006; Anadon-Irizarry, 2012), also because of its complex freshwater flux. This system is composed of many sinkholes in the geometric centre of the karst hills, which connect surface runoff with mostly subterranean rivers that emerge along the periphery of the Cockpit Country (Fincham, 1997). In many instances, it is not obvious to where the subterranean water drains, because accessibility is often limited. This unique ecosystem is under constant change, due to the relatively easy erosion of the limestone, which may result in the change of drainage systems and subterranean connections (White, 2002).
Here we investigate a freshwater species endemic to the Cockpit Country and give evidence about its genetic isolation patterns. We studied genetic variation within the troglophilic freshwater crab Sesarma fossarum (Schubart et al., 1997) showing that there is a marked trend for local endemism due to restricted gene flow throughout its distribution range. The studied species thrives in mountain creeks and small rivers, but also occurs subterraneously in caves along the western slopes of the Cockpit Country and in adjacent lowlands (Schubart et al., 1997). It belongs to the crab family Sesarmidae that experienced a marked adaptive radiation within the island's freshwaters, caves and rainforests (Schubart et al., 1998). Similar radiations were found for Jamaican lizards and frogs (Hedges, 1996; Butler et al., 2007; Losos, 2010).

As these crabs depend on freshwater rivers and streams, water divides must present a serious biogeographic barrier for dispersal (Reimer \& Schubart, 1998). As Jamaica has often changed 
geomorphological shape and thus hydrology during its history, "speciation could have occurred frequently among closely related populations" (Schubart et al., 1997: p. 417). The outcome of these events can be seen in the high current diversity of the endemic Sesarmidae on Jamaica (Schubart et al., 2010; Schubart \& Santl, 2014). Along with geographic separation, additional ecological specialization may have led to cladogenesis. Schubart et al. (1998: p. 364) suggested "that two or more radiations took place simultaneously in distinct geographic regions of Jamaica" and as evolution is in constant flux, there may be some evidence for an ongoing adaptive radiation among the species of the genus Sesarma.

In this study we examine if there is genetic differentiation and ongoing geographic differentiation in Sesarma fossarum. Furthermore, we use genetic data from several cave populations throughout the distribution range of $S$. fossarum to infer unknown subterranean water flow in the sampling area and predict the connectivity of $S$. fossarum throughout the Cockpit Country. The corresponding results should help to understand whether cave individuals are more closely related to each other than they are to surface individuals and thus if geographic isolation, or isolation by distance, is a greater contributor to population structure than habitat.

\section{METHODS}

\section{Specimen collection}

Between 1994 and 2009, 77 specimens of Sesarma fossarum were collected from twelve sampling sites (Fig. 1). Whenever possible, a minimum of ten specimens per population was gathered for statistical analyses (Table 1). Animals were killed on ice or by freezing and then preserved in 95\% ethanol.

\section{Tissue extraction, PCR and sequencing}

DNA extraction and isolation was carried out following a modified Puregene DNA Extraction Method (Gentra Systems: Minneapolis, MN55447, USA). Genomic DNA was stored in 20 $\mu 1$ TE buffer [10 mM Tris/HCL, $1 \mathrm{mM}$ EDTA $\left(\mathrm{pH} \mathrm{8.0)}\right.$ ] at $-20^{\circ} \mathrm{C}$. Cytochrome oxidase subunit I (Cox1) fragments of 661 to 790 base pairs (bp) length (including the entire "Palumbi region") were amplified by means of PCR-reaction (25 $\mu 1$ total volume) with the reverse primer COH1b (5'-TGTATARGCRTCTGGRTARTC-3' and as forward primer either COL8 (5' GAYCAAATACCTTTATTTGT-3', overall 790 basepairs (bp), including the 3 ' end of the "Folmer region") or COL1b (5'-CCWGCTGGDGGWGGDGAYCC-3' for a shorter fragment of $661 \mathrm{bp}$ ) (Schubart, 2009). This mitochondrial gene is relatively variable and is commonly used for population genetics, and more recently also for animal species identification within the barcoding approach (Hebert et al., 2003). PCR parameters consisted of denaturing at $95^{\circ} \mathrm{C}$ for $15 \mathrm{~s}$, annealing at $51^{\circ} \mathrm{C}$ for $30 \mathrm{~s}$, and elongation at $72^{\circ} \mathrm{C}$ for 1 min for 40 cycles, with a final elongation of $10 \mathrm{~min}$. Sequencing was mainly outsourced to GATC Biotech AG, Konstanz, Germany or run on a ABI PrismTM 310 Genetic Analyzer (Applied Biosystems) at the University of Regensburg.

\section{Computational analysis}

Sequences were aligned with MEGA 5.0 (http://www. megasoftware.net/) and up to $745 \mathrm{bp}$ per specimen were used for computational analysis. In order to graphically depict the genetic distance between the mitochondrial genotypes, a haplotype network was computed with TCS 1.21 (http://darwin.uvigo.es/ software/tcs.html) (calculated maximum connection steps at 95\%). Haplotype and nucleotide diversities were calculated with DnaSP v5 (http://www.ub.es/

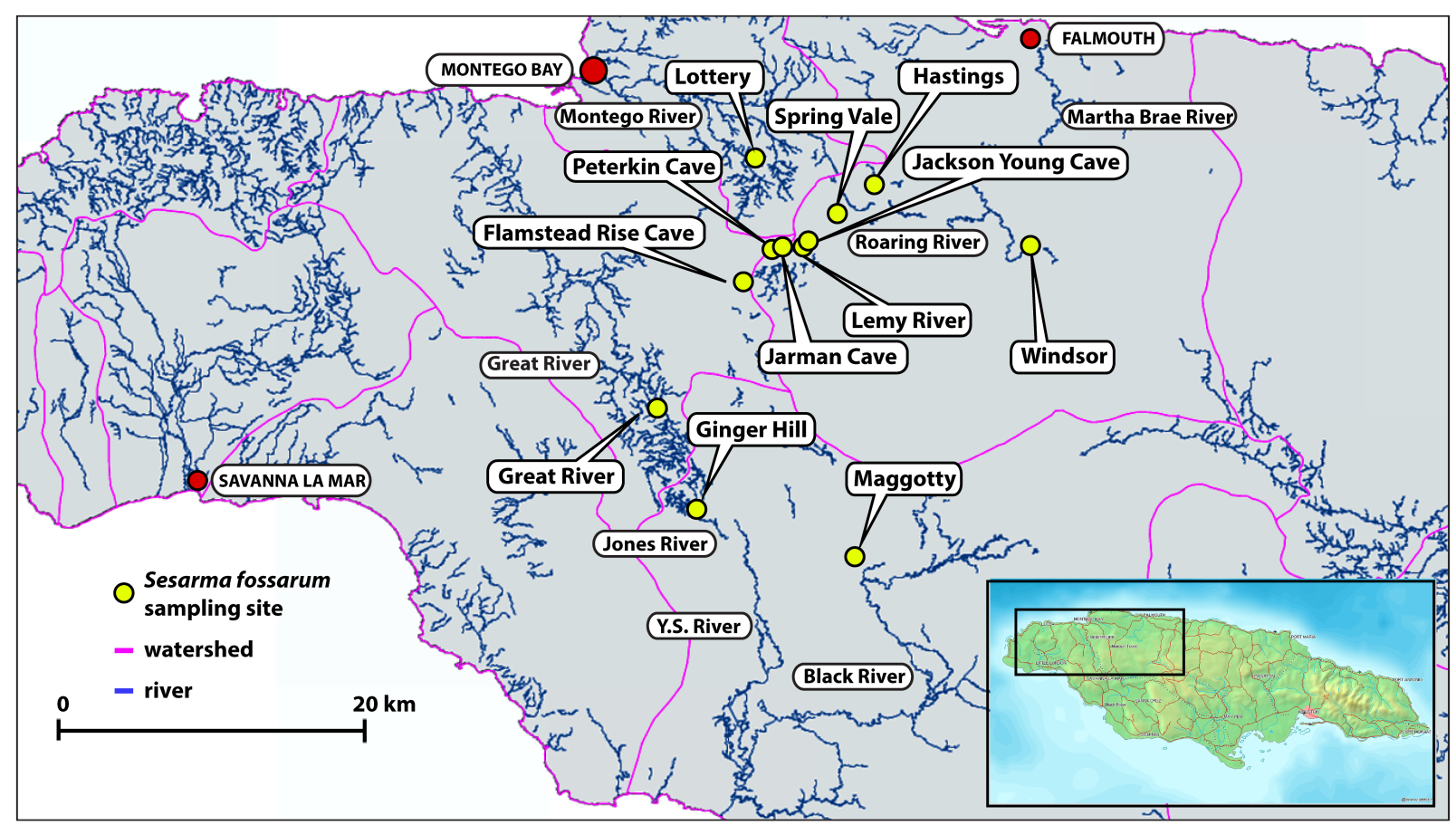

Fig. 1. Sampling sites of S. fossarum in western Jamaica (Cockpit Country). Yellow circles represent the locations of the different sampling sites of the Jamaican freshwater crabs. The hydrological map represents rivers and creeks as well as the up to date known watersheds (WRAMIS, Hydrologic Database). 
Table 1. Sampling sites of the Jamaican freshwater crab Sesarma fossarum. For each site an ID, GPS-coordinates, collection date, and number (\#) of sequenced specimens are given.

\begin{tabular}{|c|c|c|c|c|}
\hline Sample ID & Location within Jamaica & $\#$ & Coordinates & Sampling Date \\
\hline Windsor & $\begin{array}{l}\text { Windsor Great House; } \\
\text { Martha Brae River }\end{array}$ & 10 & $\begin{array}{l}18^{\circ} 21.249^{\prime} \mathrm{N} \\
77^{\circ} 38.814^{\prime} \mathrm{W} 100 \mathrm{~m}\end{array}$ & 19 February 2009 \\
\hline Hastings & $\begin{array}{l}\text { Hastings; Roaring River } \\
\text { (tributary Martha Brae R.) }\end{array}$ & 10 & $\begin{array}{l}18^{\circ} 23.350^{\prime} \mathrm{N} \\
77^{\circ} 44.687^{\prime} \mathrm{W} 110 \mathrm{~m}\end{array}$ & 20 February, 2009 \\
\hline $\begin{array}{l}\text { Jackson Young } \\
\text { Cave }\end{array}$ & $\begin{array}{l}\text { Maroon Town-Chatsworth; } \\
\text { Jackson Young Cave }\end{array}$ & 10 & $\begin{array}{l}18^{\circ} 21.282^{\prime} \mathrm{N} \\
77^{\circ} 47.243^{\prime} \mathrm{W} 410 \mathrm{~m}\end{array}$ & 18 February 2009 \\
\hline Lemy River & $\begin{array}{l}\text { Maroon Town-Chatsworth; } \\
\text { Lemy River }\end{array}$ & 10 & $\begin{array}{l}18^{\circ} 21.159^{\prime} \mathrm{N} \\
77^{\circ} 47.426^{\prime} \mathrm{W} 375 \mathrm{~m}\end{array}$ & 18 February 2009 \\
\hline Lottery & $\begin{array}{l}\text { Lottery nr. Amity Hall; } \\
\text { Montego River }\end{array}$ & 10 & $\begin{array}{l}18^{\circ} 25.133^{\prime} \mathrm{N} \\
77^{\circ} 48.867^{\prime} \mathrm{W} 115 \mathrm{~m}\end{array}$ & 19 March 2003 \\
\hline Jarman Cave & $\begin{array}{l}\text { Maroon Town-Chatsworth; } \\
\text { Jarman Bottom Cave }\end{array}$ & 9 & $\begin{array}{l}18^{\circ} 21.207^{\prime} \mathrm{N} \\
77^{\circ} 47.984^{\prime} \mathrm{W} 375 \mathrm{~m}\end{array}$ & 18 February 2009 \\
\hline Great River & Marchmont; Great River & 7 & $\begin{array}{l}18^{\circ} 15.527^{\prime} \mathrm{N} \\
77^{\circ} 52.712^{\prime} \mathrm{W} 205 \mathrm{~m}\end{array}$ & 10 October 2005 \\
\hline Ginger Hill & Ginger Hill; Jones River & 4 & $\begin{array}{l}18^{\circ} 11.893^{\prime} \mathrm{N} \\
77^{\circ} 51.378^{\prime} \mathrm{W} 325 \mathrm{~m}\end{array}$ & 13 October 2005 \\
\hline Maggotty & $\begin{array}{l}\text { Maggotty; Black River } \\
\text { tributary }\end{array}$ & 3 & $\begin{array}{l}18^{\circ} 10.150^{\prime} \mathrm{N} \\
77^{\circ} 45.617^{\prime} \mathrm{W} 125 \mathrm{~m}\end{array}$ & 22 September 2002 \\
\hline Peterkin Cave & Maldon; Peterkin Cave & 2 & $\begin{array}{l}18^{\circ} 21.055^{\prime} \mathrm{N} \\
77^{\circ} 48.226^{\prime} \mathrm{W} 415 \mathrm{~m}\end{array}$ & 1994 \\
\hline $\begin{array}{l}\text { Flamstead Rise } \\
\text { Cave }\end{array}$ & $\begin{array}{l}\text { Flamstead; Flamstead Rise } \\
\text { Cave }\end{array}$ & 1 & $\begin{array}{l}18^{\circ} 19.551^{\prime} \mathrm{N} \\
77^{\circ} 49.292^{\prime} \mathrm{W} 480 \mathrm{~m}\end{array}$ & 13 October 1997 \\
\hline Spring Vale & W of Dromilly; Spring Vale & 1 & $\begin{array}{l}18^{\circ} 22.502^{\prime} \mathrm{N} \\
77^{\circ} 45.771^{\prime} \mathrm{W} 145 \mathrm{~m}\end{array}$ & 16 June 1998 \\
\hline
\end{tabular}

dnasp/) to be able to compare genetic diversities among our sampling sites in terms of number of haplotypes and genetic distances of these haplotypes. For the network analyses and AMOVA, missing parts of shorter sequences (average sequence length: 700.4 $\mathrm{bp}$, shortest sequence: $474 \mathrm{bp}$ ) were considered to be equal to the most common haplotype within the same population. Real genetic diversity could therefore be slightly underestimated, but the general trends remain. The degree of gene flow among the populations and the level of genetic variability were tested with an Analysis of Molecular Variance, AMOVA, with Arlequin 3.11 (http://cmpg.unibe.ch/software/arlequin3/). If not stated otherwise, standard parameters were applied for each of the calculations. MrBayes 3.2.5 was applied to calculate the phylogenetic tree (majority rule consensus tree). Calculations were carried out with three million generations, four chains, sampling rate of 1000 generations and a burnin of 25\%. As an outgroup S. dolphinum (see Schubart \& Santl, 2014) was chosen.

\section{RESULTS}

The Cox1 gene fragment was amplified and sequenced from each of the collected animals. The individual sequences were aligned and did not include any gaps, and translation into amino-acid sequences did not reveal any stop codons so that no potential co-amplification of pseudogenes could be detected. In total, nine polymorphic sites were identified (five at position-1 of the open reading frame and four at position-3. Three of the former mutations lead to changes of amino-acids. The corresponding haplotype network was computed in order to visualize the genetic differences. Single mismatches in the alignment are depicted as connecting lines between groups of animals with the same haplotype. The haplotype network revealed ten different haplotypes based on nine polymorphic sites among the 77 specimens of the Jamaican endemic freshwater crab Sesarma fossarum (Fig. 2). The haplotypes were separated by a maximum of five mutational steps. Haplotype 1 is defined as the most common in the dataset and was found in 37 specimens from four populations, including all Lottery (10) and Jarman Cave (9) individuals, as well as nine out of ten samples from both Jackson Young Cave and Lemy River. Haplotype 4 is formed by nine of the ten Windsor animals and haplotype 2 consists of all ten samples from Hastings and the only Spring Vale specimen. Five animals of the Great River population belong to haplotype 7 that is also found in all four Ginger Hill and one of the Peterkin Cave specimens. Another Great River animal carried haplotype 9, which was shared with three Maggotty samples and the other available Peterkin Cave animal. Private haplotypes are found in one animal from Great River (haplotype 8), Lemy River (haplotype 6), Windsor (haplotype 5), and Jackson Young Cave (haplotype 3), all in close connection (one basepair difference) to the corresponding common haplotype of the respective population. The only animal from Flamstead Rise Cave does not share any other haplotype and has its own (haplotype 10).

In order to quantify genetic differences within the individual populations of $S$. fossarum, nucleotide and haplotype diversities were calculated. Overall, high genetic homogeneity can be recognized in most populations: not more than three haplotypes were found per sampling site, and most populations consisted of a single haplotype (Table 2). The populations Peterkin Cave $(\mathrm{h}=1, \mathrm{~N}=2)$ and Great River ( $\mathrm{h}=0.52, \mathrm{~N}=7$ ) seem to be characterized by high haplotype diversities, but the respective sample sizes, especially of Peterkin Cave, are too low.

Based on haplotype network and the nucleotide and haplotype diversities, $\Phi$ st-values and the respective p-values were calculated (Table 3). The $\Phi$ st-values are an indirect measure for the degree of gene flow between two different populations and the p-value expresses the significance of the corresponding data. The higher the $\Phi$ st-value (up to 1), the lower is potential gene flow between two populations and thus the higher genetic isolation. The populations of Maggotty, Peterkin Cave, 
Flamstead Rise Cave and Spring Vale were excluded from the analyses, due to small sample sizes. The headwaters of Great River and Ginger Hill are in close geographic vicinity (Fig. 1) and the respective samples mostly shared haplotype 7 (Fig. 2). The samples were thus pooled for the AMOVA to obtain a sample size exceeding 10. The significance level was defined at a p-value smaller than 0.05. The Windsor population reveals a strong lack of gene flow to all the other populations. The same was observed for Hastings and the pooled Great River/Ginger Hill populations. In contrast, Jackson Young Cave, Lemy River, Lottery and Jarman Cave populations are not restricted in gene flow among each other. In order to address gene flow between the northern and southern populations, we pooled the respective populations (south: Great River, Ginger Hill and Maggotty; north: remaining populations without Peterkin Cave, Flamstead Rise Cave and Spring Vale). As already recognizable in the phylogenetic tree (Fig. S1) the southern populations seem to be separated from the northern group, although it is not statistically significant (Table 3).



Fig. 2. Haplotype $(\mathrm{H})$ network showing the ten different haplotypes within the dataset of Sesarma fossarum. Each pattern represents one population. Size of circles represents the haplotype frequency. H1 (Jarman Cave, Jackson Young Cave, Lemy River, Lottery), H2 (Hastings, Spring Vale), H3 (Jackson Young Cave), H4 (Windsor), H5 (Windsor), H6 (Lemy River), H7 (Great River, Ginger Hill, Peterkin Cave), H8 (Great River), H9 (Maggotty, Great River, Peterkin Cave), H10 (Flamstead Rise Cave). Lines symbolize single nucleotide differences.

\section{DISCUSSION}

The present study provides new evidence for subterranean connections among caves in western Jamaica by means of genetic similarities in the troglophilic freshwater crab $S$. fossarum. This species can be subdivided into several populations, with complex interconnections. Relating our new data from population genetics to a hydrological map of the native range of $S$. fossarum allows to discern where the boundaries between the sampled populations lie and to predict their connectivity. This way, we can infer subterranean water flow from the presented data.

Table 2. Haplotype $(\mathrm{h})$ and nucleotide $(\Pi)$ diversities for each sampled population of the Jamaican freshwater crab Sesarma fossarum. The 77 collected specimens are distributed over 10 distinct haplotypes.

\begin{tabular}{|l|c|c|c|l|}
\hline \multicolumn{1}{|c|}{ Population } & Specimens & Haplotypes & $\mathbf{h}$ & \multicolumn{1}{|c|}{$\boldsymbol{\Pi}$} \\
\hline Windsor & 10 & 2 & 0.20 & 0.00027 \\
\hline Hastings & 10 & 1 & 0.00 & 0.00 \\
\hline $\begin{array}{l}\text { Jackson Young } \\
\text { Cave }\end{array}$ & 10 & 2 & 0.20 & 0.00027 \\
\hline Lemy River & 10 & 2 & 0.20 & 0.00027 \\
\hline Lottery & 10 & 1 & 0.00 & 0.00 \\
\hline Jarman Cave & 9 & 1 & 0.00 & 0.00 \\
\hline Great River & 7 & 3 & 0.52 & 0.00077 \\
\hline Ginger Hill & 4 & 1 & 0.00 & 0.00 \\
\hline Maggotty & 3 & 1 & 0.00 & 0.00 \\
\hline Peterkin Cave & 2 & 2 & 1.00 & 0.00134 \\
\hline $\begin{array}{l}\text { Flamstead Rise } \\
\text { Cave }\end{array}$ & 1 & 1 & - & - \\
\hline Spring Vale & 1 & 1 & - & - \\
\hline Total & 77 & $(10)$ & 0.72 & 0.00197 \\
\hline
\end{tabular}

Although there is genetic structuring in the studied species, there are not more than five basepair mutations between the most distant Cox1 haplotypes (Fig. 2), which is also reflected in the low nucleotide and haplotype diversities within the populations and in the total counts (Table 2). This indicates a high homogeneity among the populations and strengthens the evidence that the lineage of the Sesarmidae on Jamaica is relatively young, diversifying into the current species not earlier than 3.5 Myr ago, and the separations of the sister species Sesarma dolphinum versus Sesarma abeokuta, and of their ancestor versus Sesarma fossarum is probably much younger (Schubart et al., 1998; Schubart et al., 2010; Schubart \& Santl, 2014). A phylogenetic tree of the sampled populations of $S$. fossarum (see Fig. S1 in the supplementary material) and the AMOVA (Table 3) indicated a separation of the "northern" to the "southern" populations, the latter including Great River, Ginger Hill and Maggotty. Reimer et al. (1998) suggested that changing watersheds could also be responsible for the isolation of a population. It seems to be that there is at least one water divide, which maintains the isolation of the sampled populations. As S. fossarum is restricted to rivers, it is strongly dependent on water and its immediate surroundings. Taking into account the results from the haplotype network (Fig. 2) and the AMOVA (Table 3), the restriction of gene flow between the sampled populations can be plotted on a map. Hence, one hypothetical water divide can be drawn somewhere between Jarman Cave and Great River (Table 3, Fig. 3). Interestingly, the studied cave populations do not differ genetically from nearby surface populations, despite the observed morphometric differences (Stemmer \& Schubart, 2013). The Hastings population obviously drains over the Roaring River to the east 
Table 3. Gene flow between sampling sites. Given are $\Phi$ st- values and their corresponding p-values of the Jamaican freshwater crab Sesarma fossarum of all sampling sites compared with each other; $+: p<0.001$ (very significant). Southern sampling sites include Great River, Ginger Hill, and Maggotty.

\begin{tabular}{|l|c|c|c|c|c|c|c|c|c|}
\hline \multicolumn{1}{|c|}{ p-value } & WIN & HAS & JYC & LEM & LOT & JAR & $\begin{array}{c}\text { GRE/ } \\
\text { GIN }\end{array}$ & N & S \\
\cline { 1 - 8 } \multicolumn{1}{|c|}{ Windsor } & & + & + & + & + & + & + & & + \\
\hline Hastings & 0.9091 & & + & + & + & + & + & & + \\
\hline $\begin{array}{l}\text { Jackson } \\
\text { Young Cave }\end{array}$ & 0.8333 & 0.9524 & & - & - & - & + & & + \\
\hline Lemy River & 0.8333 & 0.9524 & $<0.0001$ & & - & - & + & & + \\
\hline Lottery & 0.9091 & 1.0000 & $<0.0001$ & $<0.0001$ & & - & + & & + \\
\hline Jarman Cave & 0.9042 & 1.0000 & $<0.0001$ & $<0.0001$ & $<0.0001$ & & + & & + \\
\hline $\begin{array}{l}\text { Great River/ } \\
\text { Ginger Hill }\end{array}$ & 0.8640 & 0.9364 & 0.9078 & 0.9078 & 0.9364 & 0.9330 & & & \\
\hline North & & & & & & & & & - \\
\hline South & 0.7775 & 0.8784 & 0.8538 & 0.8538 & 0.8784 & 0.8732 & & 0.6660 & \\
\hline
\end{tabular}

and shares the drainage system with the Windsor population, but nevertheless the two populations surprisingly do not share haplotypes and thus lack gene flow between them (Table 3, Fig. 3). Spring Vale belongs to the Hastings population according to the haplotype network (Fig. 2). This was already assumed (Fincham, 1997) because water from this cave was predicted to exit as the spring of the Roaring River in Hastings. The $\Phi$ st-values reveal that the populations of Jarman Cave, Jackson Young Cave, Lemy River and Lottery are not restricted in gene flow and as they show no gene flow to all the other populations, it can be proposed that the streams from which these animals were collected drain towards the north into the Montego River. The Great River/Ginger Hill group is located in the southwest and is restricted in gene flow to all other populations. These two locations are geographically very close to each other, but belong to two different rivers (Fig. 3). The current data suggest that Ginger Hill and Great River animals are genetically identical (Fig. 2) and were therefore pooled for the AMOVA analyses. An explanation for this observation could be that the headwaters of both rivers are in close vicinity or were even connected in the past. The Maggotty population has probably no gene flow to any other population (Fig. 2), but this was not tested with AMOVA, due to the small sample size. This observation appears obvious as this population is also geographically separated from the rest and the corresponding stream drains from the northeast into the Black River (Fig. 3). Nevertheless, the haplotype network shows that Maggotty and one Great River specimens share the same haplotype, suggesting another recent connection or translocation. Furthermore, the relation of Spring Vale, Flamstead Rise Cave and Peterkin Cave to the others can only be guessed, but more material would provide some interesting additional information about the substructure and the water divides in this region. Furthermore, additional genetic markers need to be included in order to fully resolve the isolation patterns of $S$. fossarum.

Overall, it appears that the underwater system is more complex than thought (Fincham, 1997), connecting some parts of the area underground. Hence, destruction of one side of that ecosystem can lead to the loss of unique evolutionary units and/ or influence the connected sites as well (Beckford \& Bailey, 2009). Unfortunately, the Cockpit Country, which was shaped over millions of years, is attracting commercial interests and foreign investors, especially for bauxite mining that has already destroyed some parts of it (Chenoweth et al., 2001; Day \& Chenoweth, 2009). Moreover, an expansion of the mining area is planned deeper into the Cockpit Country that within a few decades could provoke the disappearance of endemic species or populations, associated with this habitat (Watson et al., 1997; Hamilton-Smith, 2001). For example, the populations in the south (Great River, Ginger Hill and Maggotty) could already be affected by these mining operations, which have the potential to ultimately change watersheds and hence the dispersal of water-dependent species in this area.

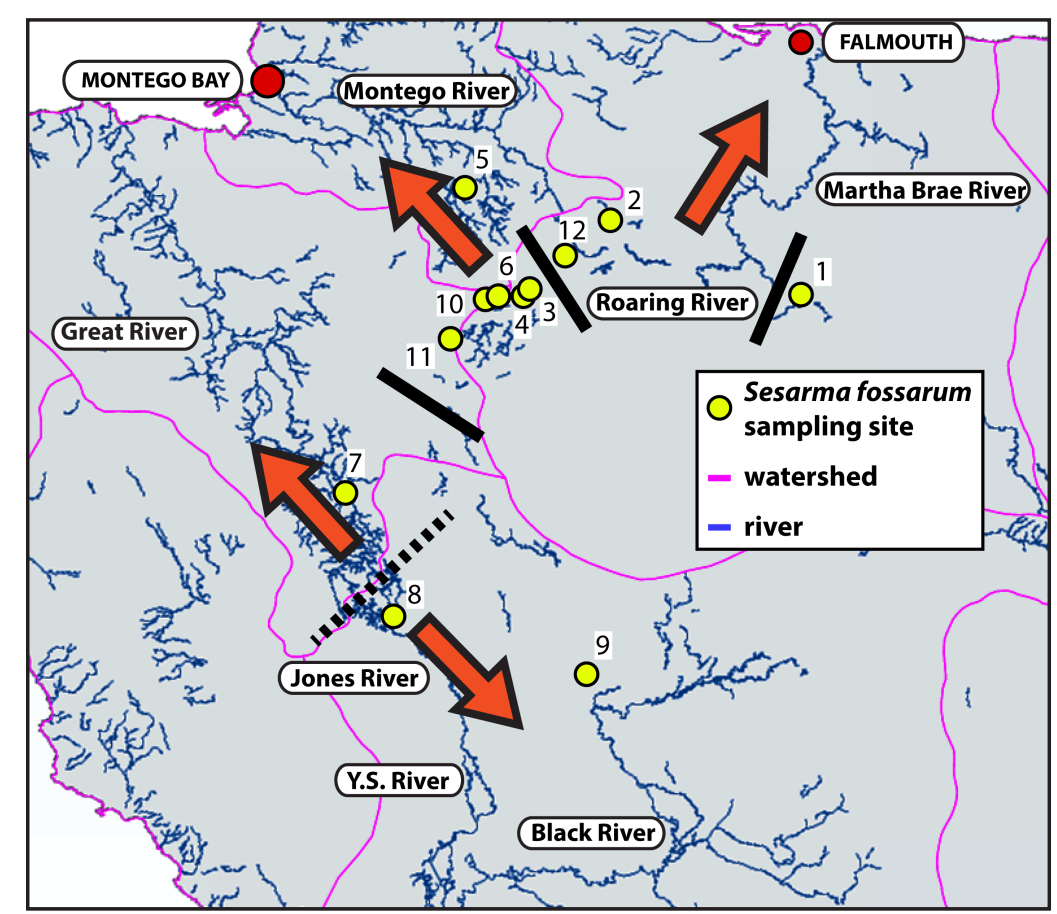

Fig. 3. Genetic isolation among $S$. fossarum populations, shown on a hydrological map of western Jamaica (Cockpit Country). Black bars represent the hypothesized water divides isolating populations of freshwater crabs based on the current results. The red arrows show the postulated direction of dispersal of these populations, following the big river systems (blue). 1) Windsor; 2) Hastings; 3) Jackson Young Cave; 4) Lemy River (referred to Leme in Stemmer \& Schubart 2013); 5) Lottery; 6) Jarman Cave; 7) Great River; 8) Ginger Hill; 9) Maggotty; 10) Peterkin Cave; 11) Flamstead Rise Cave; 12) Spring Vale. 


\section{CONCLUSIONS}

The geological history and karst structure of the Cockpit Country are main factors for the complex structuring of the species Sesarma fossarum and probably also for many other species. The results show that $S$. fossarum has a relatively high intraspecific diversity and geographic substructure similar to Sesarma dolphinum (see Schubart et al., 2010; Schubart \& Sant1, 2014) and that this is probably a general feature of the adaptive radiation of the Sesarmidae on Jamaica and seems to differ from freshwater crabs in the other Caribbean islands (Schubart et al., 2011). The endemic species of Jamaica are excellent models to show how evolution is driving diversification within a geomorphologically diverse environment and will allow even more insights in future studies.

The previously identified watersheds (WRAMIS) are clearly oversimplified and most probably do not represent the actual drainage system and may need to be revised. The here presented study can serve as an example about how population genetics can be utilised to refine hydrological and topographic maps. In order to do so, more samples need to be collected, more sites need to be taken into account and additional genetic markers need to be incorporated. In the future, population genetic data from several species could be combined in order to get an even more accurate map of ecological and geological interconnections.

\section{ACKNOWLEDGEMENTS}

We thank Rudolf Diesel, Tobias Santl, Silke Reuschel, Hung-Chang Liu, Renae Brodie, Miguel Lopez and Nicole Rivera for their help in gathering sufficient specimens of Sesarma fossarum over the years. Susan Koenig, Michael Schwartz and Sugarbelly from Windsor Great House are acknowledged for their hospitality and especially for their great and endless efforts to preserve the wonderful and precious Cockpit Country. We also thank Theodor Pöttinger for computational assistance. Research was funded through a six year research grant to Christoph D. Schubart (Schu 1460/3) through the Deutsche Forschungsgemeinschaft within the priority program 1127: "Adaptive Radiation - Origin of Biological Diversity".

\section{REFERENCES}

Anadón-Irizarry V., Wege D.C., Upgren A., Young R., Boom B., León Y.M., Arias Y., Koenig K., Morales A.L., Burke W., Perez-Leroux A., Levy C., Koenig S., Gape L. \& Moore P., 2012 - Sites for priority biodiversity conservation in the Caribbean Islands Biodiversity Hotspot. Journal of Threatened Taxa, 4: 2806-2844.

http://dx.doi.org/10.11609/JoTT.o2996.2806-44

Butler M.A., Sawyer S.A. \& Losos J.B., 2007 - Sexual dimorphism and adaptive radiation in Anolis lizards. Nature, 447: 202-205.

http://dx.doi.org/10.1038/nature05774
Beckford C.L. \& Bailey S.W., 2009 - Vulnerability, constraints and survival on small-scale food farms in St Elizabeth, Jamaica: Strengthening local food production systems. Global Change and Caribbean Vunerability: Environment, economy and society at risk, 218-236.

Chenoweth M., Day M. \& Koenig S., 2001 - Conservation issues in the Cockpit Country, Jamaica. $13^{\text {th }}$ International Congress of Speleology, $4^{\text {th }}$ Speleological Congress of Latin América and Caribbean, 26 ${ }^{\text {th }}$ Brazilian Congress of Speleology, Brasilia, DF, 651-655.

Clements R., Sodhi N.S., Schilthuizen M. \& Ng P.K.L., 2006 - Limestone karsts of Southeast Asia: Imperiled arks of biodiversity. BioScience, 56: 733.

http://dx.doi.org/10.1641/0006-

3568(2006)56[733:LKOSAI]2.0.CO;2

Day M. \& Chenoweth S., 2009 - Potential impacts of anthropogenic environmental change on the Caribbean karst. In: McGregor D., Dodman D., and Barker D. (Eds.), Global change and Caribbean vulnerability: environment, economy and society at risk. Kingston: The University of the West Indies Press: 100-122.

Fincham A.G., 1997 - Jamaica underground: The caves, sinkholes and underground rivers of the island. Kingston, $447 \mathrm{p}$.

Hamilton-Smith E., 2001 - Current initiatives in the protection of karst biodiversity. Natura Croatica, 10: 229-243.

Hebert P.D.N., 2003 - Barcoding animal life: cytochrome $c$ oxidase subunit 1 divergences among closely related species. Proceedings of the Royal Society B, 270: 96-99. http://dx.doi.org/10.1098/rsbl.2003.0025

Hedges S.B., 1996 - Historical biogegraphy of West Indian vertebrates. Annual Review of Ecology and Systematics, 27: 163-196. http://dx.doi.org/10.1146/annurev.ecolsys.27.1.163

Losos J.B., 2010 - Adaptive radiation, ecological opportunity, and evolutionary determinism. The American Naturalist, 175: 623-639. http://dx.doi.org/10.1086/652433

Reimer J., Schubart C.D. \& Diesel R., 1998 - Description of a new freshwater crab of the genus Sesarma Say, 1817 (Brachyura, Grapsidae, Sesarminae) from Western Jamaica. Crustaceana, 71: 185-196.

http://dx.doi.org/10.1163/156854098X00167

Schubart C.D., 2009 - Mitochondrial DNA and decapod phylogenies: The importance of pseudogenes and primer optimization. In: Martin J.W., Crandall K.A. \& Felder D.L. (Eds.), Decapod crustacean phylogenetics. Boca Raton: CRC Press: p. 47-65.

http://dx.doi.org/10.1201/9781420092592-c4

Schubart C.D. \& Santl T., 2014 - Differentiation within a river system: Ecology or geography driven? Evolutionary significant units and new species in Jamaican freshwater crabs. In: Yeo D.C.J., Cumberlidge N. \& Klaus S. (Eds.), Advances in freshwater decapod systematics and biology. Leiden/Boston: Brill: 162-173.

http://dx.doi.org/10.1163/9789004207615 011

Schubart C.D., Diesel R. \& Hedges S.B., 1998 Rapid evolution to terrestrial life in Jamaican crabs. Nature, 393: 363-365.

http://dx.doi.org/10.1038/30724

Schubart C.D., Reimer J., Diesel R. \& Türkay M., 1997 - Taxonomy and ecology of two endemic freshwater crabs from western Jamaica with the description of a new Sesarma species (Brachyura: Grapsidae: Sesarminae). Journal of Natural History, 31: 403-419. http://dx.doi.org/10.1080/00222939700770201 
Schubart C.D., Rivera N.T., Crandall K.A. \& Santl T., 2011 - Shallow phylogeographic structure of Puerto Rico freshwater crabs: an evolutionary explanation for low species diversity compared to Jamaica. In: Held C., Koenemann S. \& Schubart C.D. (Eds.), Crustacean issues 19: Phylogeography and population genetics in Crustacea. Boca Raton: Taylor \& Francis/CRC Press: p. 345-381.

Schubart C.D., Weil T., Stenderup J.T., Crandall K.A. \& Santl T., 2010 - Ongoing phenotypic and genotypic diversification in adaptively radiated freshwater crabs from Jamaica. In: Glaubrecht M. (Ed.), Evolution in action. Berlin/Heidelberg: Springer Berlin Heidelberg: p. 323-349.

http://dx.doi.org/10.1007/978-3-642-12425-9 16
Stemmer M. \& Schubart C.D., 2013 - Allopatric differentiation and morphometric growth in a Jamaican freshwater crab, with the discrimination of a cave phenotype. Studies on Neotropical Fauna and Environment, 48: 95-103.

http://dx.doi.org/10.1080/01650521.2013.835614

Sweeting M.M., 1958 - The karstlands of Jamaica. Geography Journal, 124: 184-199.

http://dx.doi.org/10.2307/1790245

Watson J., Hamilton-Smith E., Gillieson D. \& Kiernan K., 1997 - Guidelines for cave and karst protection. IUCN, Gland, Switzerland, 63 p.

White W.B., 2002 - Karst hydrology: Recent developments and open questions. Engineering Geology, 65: 85-105. http://dx.doi.org/10.1016/S0013-7952(01)00116-8 